\title{
Epidemiologia delle resistenze di Helicobacter pylori alle sostanze antibatteriche piú utilizzate nella terapia di eradicazione (Ospedale di Merano I 998 - 2002)
}

\author{
Mario V. Zanetti \\ Laboratorio di Microbiologia, Ospedale "F.Tappeiner", Merano (BZ)
}

Key Words: PPI, FISH test.

\section{SUMMARY}

Bacterial resistance to antibiotics represents one of the most important factors of treatment failure for infectious diseases. In Helicobacter pylori (HP) infection, this aspect is of dramatic importance when considering eradication therapy which according to the most recent consensus conference implies an association of a proton pump inhibitor (PPI) and two antibiotics (mainly nitromidazoles, macrolides and beta-lactames).

Beside the strong recommendation after treatment failure, in-vitro test of resistance of the mostly used antibiotics, has gained also an increasing importance over time due to the progressive increase of resistance observed with most used substances as, for example, macrolides.

Metronidazole (MTR) and Clarithromycin (CLA) are almost routinely tested in our laboratory in cultures from HPpositive gastric biopsies using the disk diffusion technique (fig. I), in-vitro resistance to Amoxicillin (AMX) is only tested if specifically requested from the clinician.

A retrospective analysis of culture results from gastric biopsies taken during gastroscopy performed in the endoscopy unit of our hospital over the last quinquennial, allowed us to monitor the prevalence of HP resistance to MTR e CLA and to assess their possible relationship with age and gender. Furthermore we studied the impact of resistance on typer of eradication therapy as well as the onset of secondary resistance and the stability of CLA resistance.

We have therefore considered an overall number of 1039 HP-positive cultures. Among them, $54,3 \%$ were resistant to both antibiotics being $34,7 \%$ resistant to MTR, and $18,6 \%$ resistant to CLA, and I2,I\% resistant to both substances (fig.2).

According to gender, data on antibiotic resistance of HP, show no difference for CLA (I7,2\% for $O^{7}$ and $20,1 \%$ for ()), whereas MTR resistance is significantly more frequently observed in women ( $29,3 \%$ for $\sigma^{7}$ and $40,1 \%$ ) ). This result may probably be related to the use of MTR by ginecologist for pelvic infection. Based on the antibiotic association, it may be speculated a synergic activity of the combination of MTR and CLA. In a group of patients $(n=19)$ after eradication failure, a secondary antibiotic resistance was observed in $36,9 \%$; namely $21,1 \%$ for MTR and I5,8\% for CLA. In-vitro stability of resistance of the latter substance was $59,1 \%$.

\section{RELAZIONE:}

La resistenza dei batteri agli antibiotici costituisce un importante fattore di fallimento del trattamento delle malattie da infezione. Nel caso di infezione da Helicobacter pylori (HP) il fenomeno diviene particolarmente importante quando si intraprende una terapia eradicante che, secondo le piú consolidate e recenti linee-guida emanate nelle ultime Consensus Conferences, comporta l'impiego simultaneo di un inibitore della secrezione gastrica (PPI) e di due sostanze antibiotiche (per lo piú nitroimidazoli , macrolidi, betalattamici).

Il saggio in vitro quindi della resistenza alle sostanze antibatteriche piú utilizzate nei protocolli di eradicazione di HP, ha assunto nel corso degli anni maggior importanza soprattutto in relazione al progressivo aumento delle resistenze registrato nei confronti di alcune molecole molto utilizzate (es. macrolidi), oltre ad essere fortemente raccomandato dopo un insuccesso della terapia eradicante (Mastricht 22000 Consensus Report).

In laboratorio le prove di sensibilità di HP agli antibiotici maggiormente utilizzate sono l'agar dilution, l'e-test, il FISH test (fluorescent in situ hybridization) e, quello da noi utilizzato, il "disk diffusion" o Kirby-Bauer modificato.

Quest'ultima, tecnica semplice e riproducibile, presenta numerosi vantaggi tra cui il basso costo e la facile interpretazione dei risultati che peraltro rispetto alle altre due metodiche citate sono soltanto di tipo qualitativo. Anche se NCCLS non ha emanato criteri interpretativi chiari, ormai numerosi studi internazionali hanno basato le loro conclusioni utilizzando "disk diffusion" come 
metodo di misura della sensibilità di HP agli antimicrobici. Per esperienza personale con questa metodica consiglio innanzitutto di utilizzare colture giovani (non più di 2-3 gg.) per limitare al massimo la presenza di forme coccoidi e di seguire alcuni semplici accorgimenti : sospensioni per sub-colture a 3-4 McFarland di torbidità , utilizzo per le sub-colture di piastre di Mueller-Hinton agar addizionate col 5\% di sangue di montone $(\varnothing$ $9 \mathrm{~mm}$.) su cui testare contemporaneamente non più di 3 dischetti impregnati di antibiotico, allestimento delle piastre stesse con porte e finestre ben chiuse ad evitare facili inquinamenti da miceti, condizioni di incubazione delle piastre, che si comincieranno ad osservare dopo 2 giorni, simili a quelle delle colture primarie $\left(\mathrm{CO}_{2}\right.$ tra $5-10 \%$, $\mathrm{O}_{2}$ tra 5-7\% ed umidità intorno al $95 \%$ ).

Mentre la resistenza in vitro di Amoxicillina $(A M X)$, antibiotico largamente utilizzato nei protocolli di eradicazione di HP, viene saggiata nel nostro laboratorio solo su specifica richiesta del clinico specialista, Metronidazolo (MTR) e Claritromicina $(C L A)$ vengono testati di routine nelle colture da biopsie gastriche positive per HP. Un'analisi retrospettiva dei risultati delle prove di sensibilità, riferite all'ultimo quinquennio, delle colture di HP da biopsie gastriche prelevate in corso di esame gastroscopico, eseguito negli ambulatori di Endoscopia digestiva del nostro ospedale, ci ha permesso di monitorare in particolare le prevalenze di resistenze di HP a MTR e CLA in relazione a fasce d'età, al sesso, alla significatività sulla percentuale di eradicazione anche in riferimento al protocollo di terapia adottato , all' eventuale sviluppo di resistenze secondarie e di studiare la stabilità della resistenza in ceppi CLAresistenti.

Sono state considerate 1039 colture HP positive provenienti da pazienti che nei tre mesi precedenti l'esame gastroscopico non avevano assunto antibiotici , né avevano iniziato alcuna terapia di eradicazione per HP. Il saggio di sensibilità a MTR e CLA è stato effettuato con la tecnica "disk diffusion" utilizzando dischetti da $5 \mathrm{mg}$ per MTR e da $15 \mathrm{mg}$ per CLA su terreno MuellerHinton agar addizionato con $5 \%$ di sangue di montone e con le condizioni di incubazione schematizzate in figura 1.

Di queste colture sono risul- tate resistenti ad entrambe le sostanze antimicrobiche il 54,3\% $(\mathrm{n}=565)$ (fig. 2$)$.

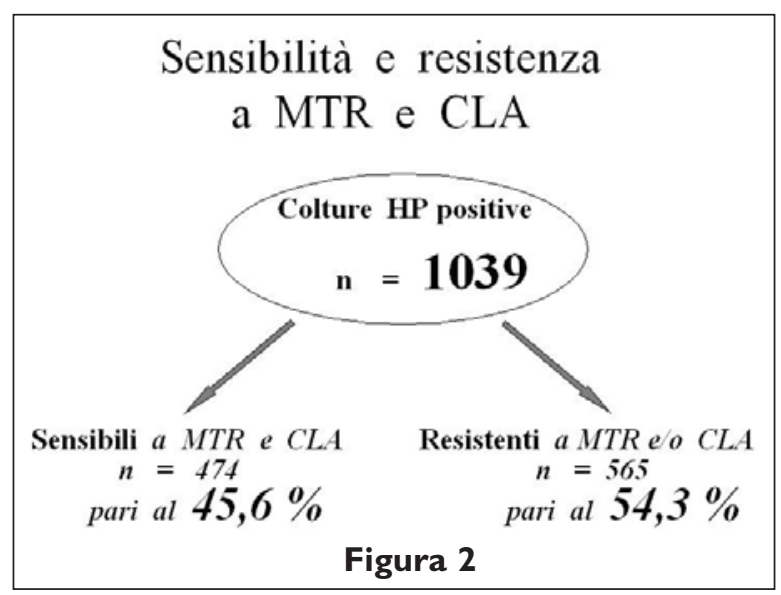

In particolare il $34,7 \%(\mathrm{n}=361)$ era resistente a MTR, il 18,6\% $(\mathrm{n}=193)$ resistente a CLA ed il $\mathbf{1 2 , 1 \%}(\mathrm{n}=126)$ presentava una doppia resisten$z a$ (fig.3).

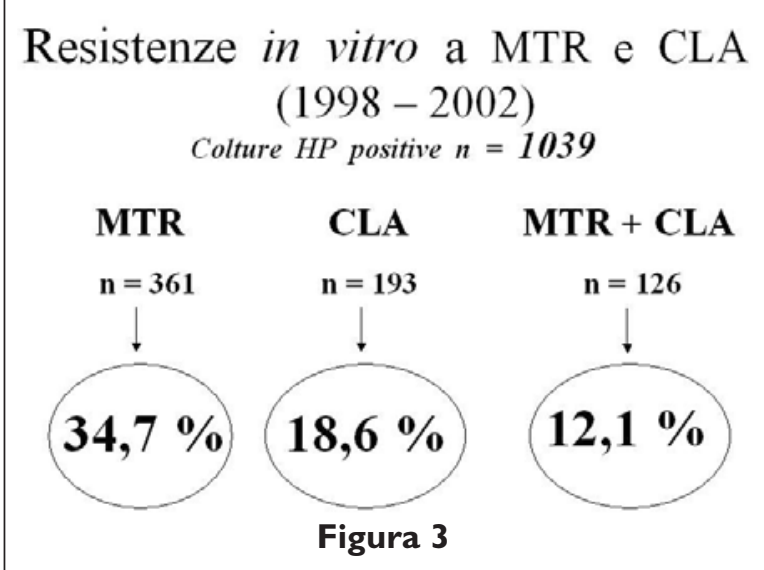

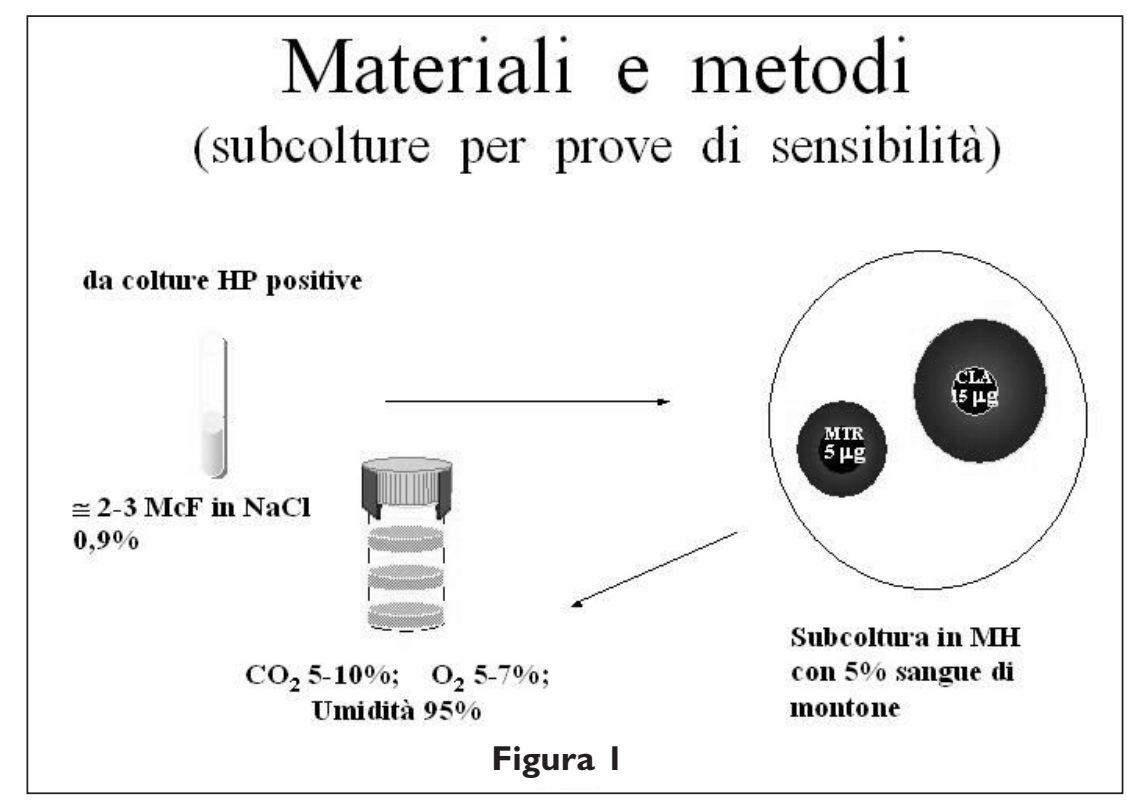


Andando a valutare l'incremento delle resistenze nel quinquennio considerato si può osservare il passaggio per MTR dal 32,8\% nel 1998 al 36,5\% a fine 2002 , mentre per CLA si passa dal $15,1 \%$ nel 1998 al 22,2\% a fine 2002 (fig.4)

\section{Prevalenza di resistenze a MTR e CLA per anno (1998-2002)}

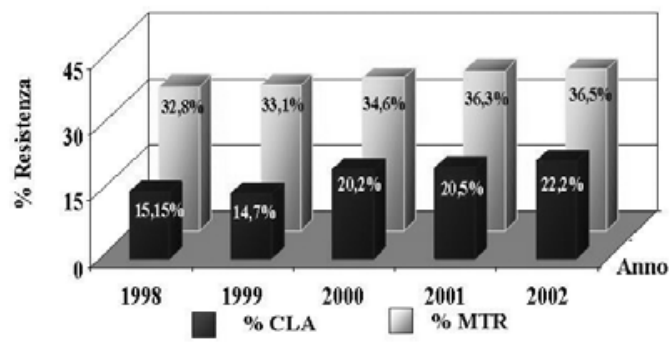

Figura 4

Per quanto riguarda la distribuzione della prevalenza di resistenze in relazione alle fasce di età è evidente che mentre per MTR, a parte la classe $<35$ anni $(30,5 \%)$, le altre classi d'età non presentano variazioni significative tra di loro $(d a$ $35,5 \%$ a $36,5 \%$ ), mentre per CLA partendo da un $11,8 \%$ per la classe $<35$ anni si arriva ad un massimo di $25,8 \%$ per quella $>65$ anni passando da un picco di 19,8\% per la classe 50-65 anni (fig.5)

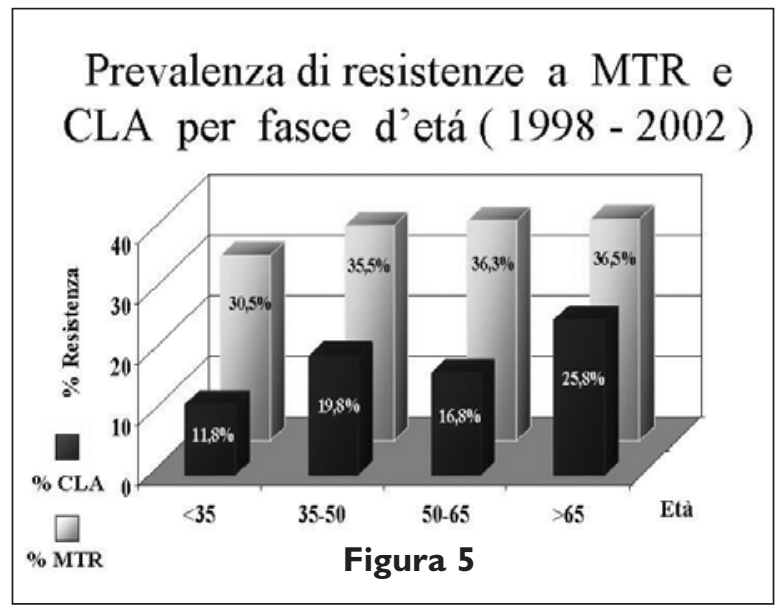

Analizzando la prevalenza di resistenze in relazione al sesso si può notare (fig. 3) come mentre per CLA non sia significativa (17,2\% per $\sigma^{7} \mathrm{e}$ $20,1 \%$ per O) per MTR è fortemente dipendente $\left(29,3 \%\right.$ per $\sigma^{7}$ e $40,1 \%$ per + ), ciò soprattutto perché MTR viene notoriamente impiegato in ambito ginecologico in caso di infezioni pelviche (fig.6).

L'analisi dei dati delle percentuali di eradicazione di HP in relazione alla sensibilità/resistenza in vitro del ceppo di HP in esame in un gruppo ristretto $(\mathrm{n}=111)$ di pazienti HP positivi (fig. 7), ed ancor di più la distinzione di quelle percentuali in base al protocollo di terapia adottato (fig. 8), permettono di evidenziare come la resistenza in vitro di MTR appaia scarsamente rilevante da un punto di vista clinico [\% di eradicazione sovrapponibile $(89 \%$ per MTRres vs.91\% per MTRsens)], mentre la resistenza in vitro di CLA ha un notevole impatto nella terapia di eradicazione con riduzione notevole del tasso di eradicazione stesso $(65 \%$ per CLAres vs. $91 \%$ per

\begin{tabular}{|c|c|c|c|c|c|}
\hline \multicolumn{6}{|c|}{$\begin{array}{c}\text { Resistenze a MTR e CLA } \\
\text { in relazione al sesso }\end{array}$} \\
\hline Sesso & $n$ & $M T R R$ & $C L A R$ & ${ }^{\circ} \mathrm{MTRR}$ & ${ }^{\circ}{ }_{0} L A R$ \\
\hline M & 547 & 162 & 94 & 29,31 & 17,18 \\
\hline F & 492 & 199 & 99 & 40,14 & 20,12 \\
\hline Totale & 1039 & 361 & 193 & 34,7 & 18,6 \\
\hline \multicolumn{6}{|c|}{ Figura 6} \\
\hline
\end{tabular}

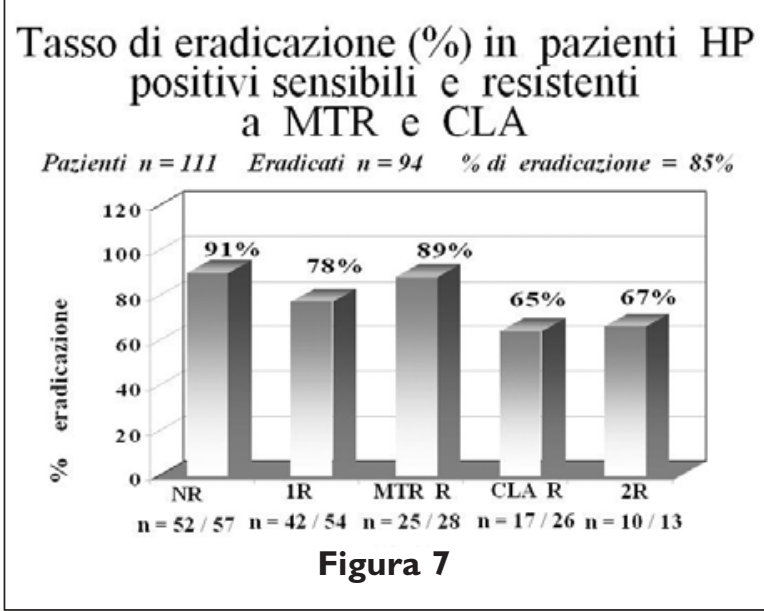

Eradicazione dopo terapia tripla $(\mathrm{PPI}+\mathrm{MC} / \mathrm{AC}$ ) vs. MTR-R e CLA-R

Pazienti $n=111$ Trattati con OMC $n=74$, con OAC $n=37$

\begin{tabular}{|c|c|c|c|c|}
\hline Totali & $\begin{array}{c}94 / 111 \\
(85 \%)\end{array}$ & $\begin{array}{l}52 / 57 \\
(91 \%)\end{array}$ & $\begin{array}{l}25 / 28 \\
(89 \%)\end{array}$ & $\begin{array}{l}17 / 26 \\
(65 \%)\end{array}$ \\
\hline OMC & $\begin{array}{l}65 / 74 \\
(88 \%)\end{array}$ & $\begin{array}{l}36 / 40 \\
(90 \%)\end{array}$ & $\begin{array}{l}17 / 19 \\
(89 \%)\end{array}$ & $\begin{array}{l}12 / 15 \\
(80 \%)\end{array}$ \\
\hline OAC & $\begin{array}{l}29 / 37 \\
(78 \%)\end{array}$ & $\begin{array}{l}16 / 17 \\
(94 \%)\end{array}$ & $\begin{array}{c}8 / 9 \\
(89 \%)\end{array}$ & $\begin{array}{c}5 / 11 \\
(45 \%)\end{array}$ \\
\hline
\end{tabular}

Figura 8 
CLAsens). Risulta inoltre evidente una sorta di sinergismo nell' attività eradicante quando MTR e CLA vengono impiegati contemporaneamente.

In un gruppo $(\mathrm{n}=19)$ di pazienti HP positivi , in cui era stato intrapreso, con insuccesso, il trattamento terapeutico eradicante, è stata rilevata l'insorgenza di resistenze secondarie (36,9\%) ; in particolare il $15,8 \%$ aveva una resistenza secondaria a CLA ed il 21,1\% a MTR (fig. 9).

\section{Resistenze secondarie a CLA e MTR} (pazienti HP positivi dopo trattamento con TT)

Pazienti non eradicati $n=19$

Almeno una resistenza secondaria $7 / 19=36,9^{\circ} \%$ di cui

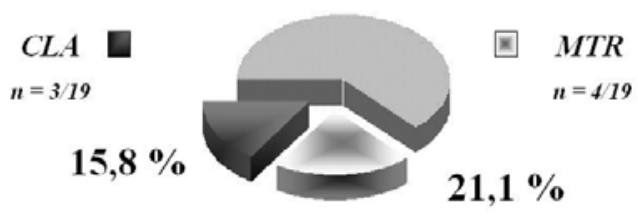

Figura 9

Opinioni discordi vi sono poi, da parte di diversi studiosi dell'argomento, sulla stabilità della resistenza a CLA da parte di HP. E' stato perciò preso in esame un gruppo di pazienti HP positivi e CLA resistenti $(\mathrm{n}=22)$ : i ceppi CLA resistenti sono stati sub-coltivati fino a $20-25$ volte su piastre di Mueller-Hinton agar con 5\% di montone in presenza di un dischetto di CLA da $15 \mu \mathrm{g}$ ed osservati ogni 3-5 giorni per valutare l'eventuale riacquisizione della sensibilità a CLA (fig. 10).

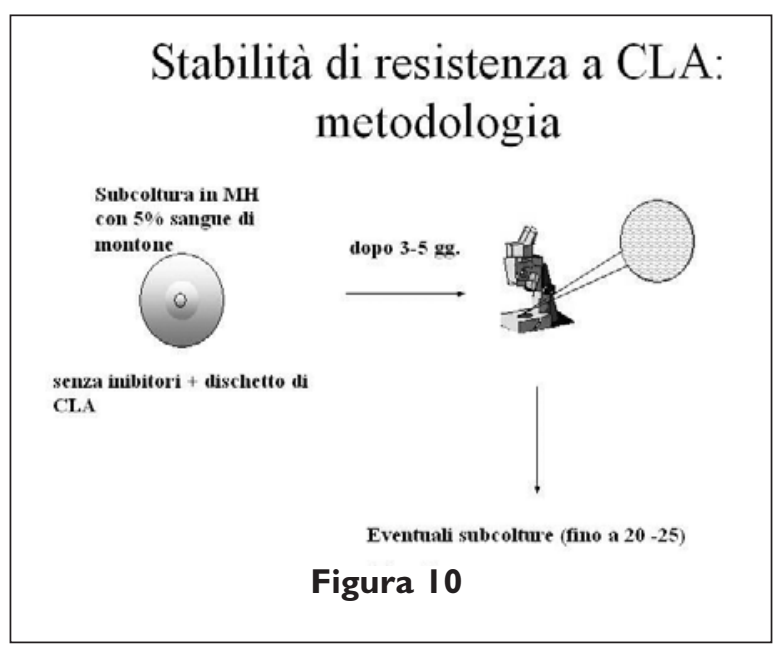

Le colture rimanevano resistenti a CLA dopo 2025 subcolture nel gruppo citato, abbiamo cioè notato una stabilità di resistenza a CLA, nel $59,1 \%$ dei casi con un ritorno quindi alla sensibi- lità a CLA nel 40,9\% dei ceppi (fig. 11).

In conclusione, nella nostra area geografica, la prevalenza di resistenza a MTR è pressoché doppia percentualmente rispetto a quella di CLA (fig. 12) Quest'ultima risulta maggiore nel sesso femminile e comporta un notevole impatto, a differenza di quella riferita a MTR, nella terapia di eradicazione con riduzione notevole del tasso di eradicazione stesso.

\section{Stabilità di resistenza a CLA}

\section{Colture CLA resistenti esaminate $n=22$ di cui (dopo 20-25 subcolture)}

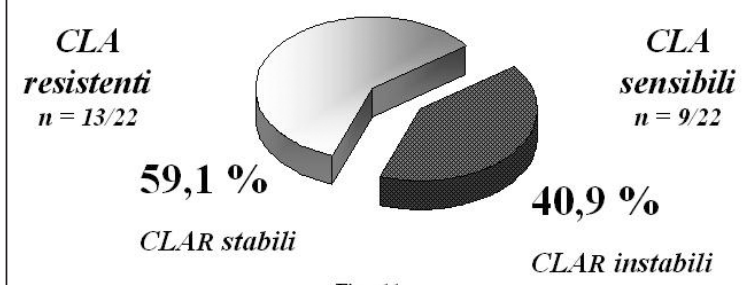

Fïgura II

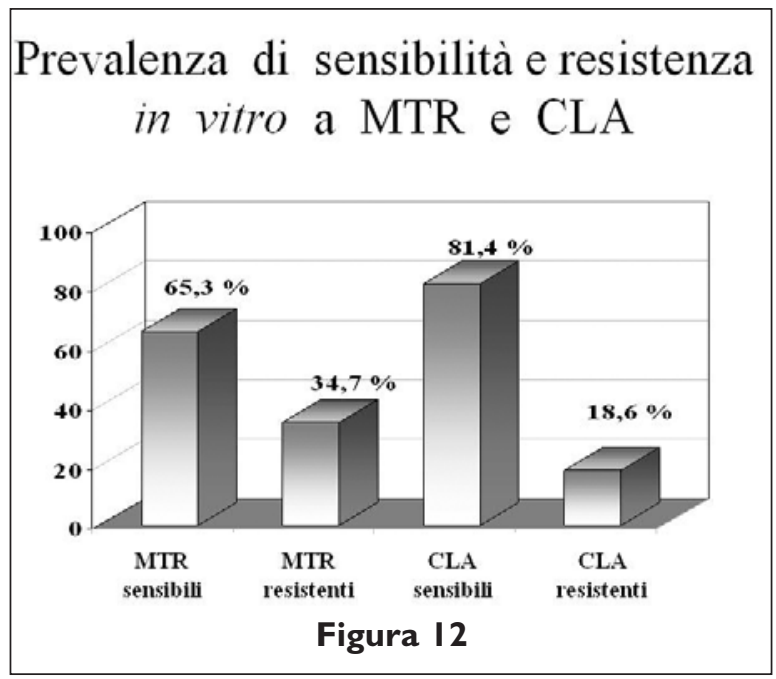

E' consigliabile la prova di sensibilità in vitro agli antibiotici, soprattutto prima dell'impiego di un macrolide nella terapia di eradicazione di HP e, a maggior ragione, dopo fallimento della terapia stessa (fig. 13).

È comunque opportuno tener presente che, in vivo, la terapia multipla si avvale dell'azione sinergica di un PPI e 2 antibiotici (azione sul PH e batteriostatica + azione battericida) che limita notevolmente la comparsa di resistenze e comunque ne minimizza gli effetti (fig. 14). 

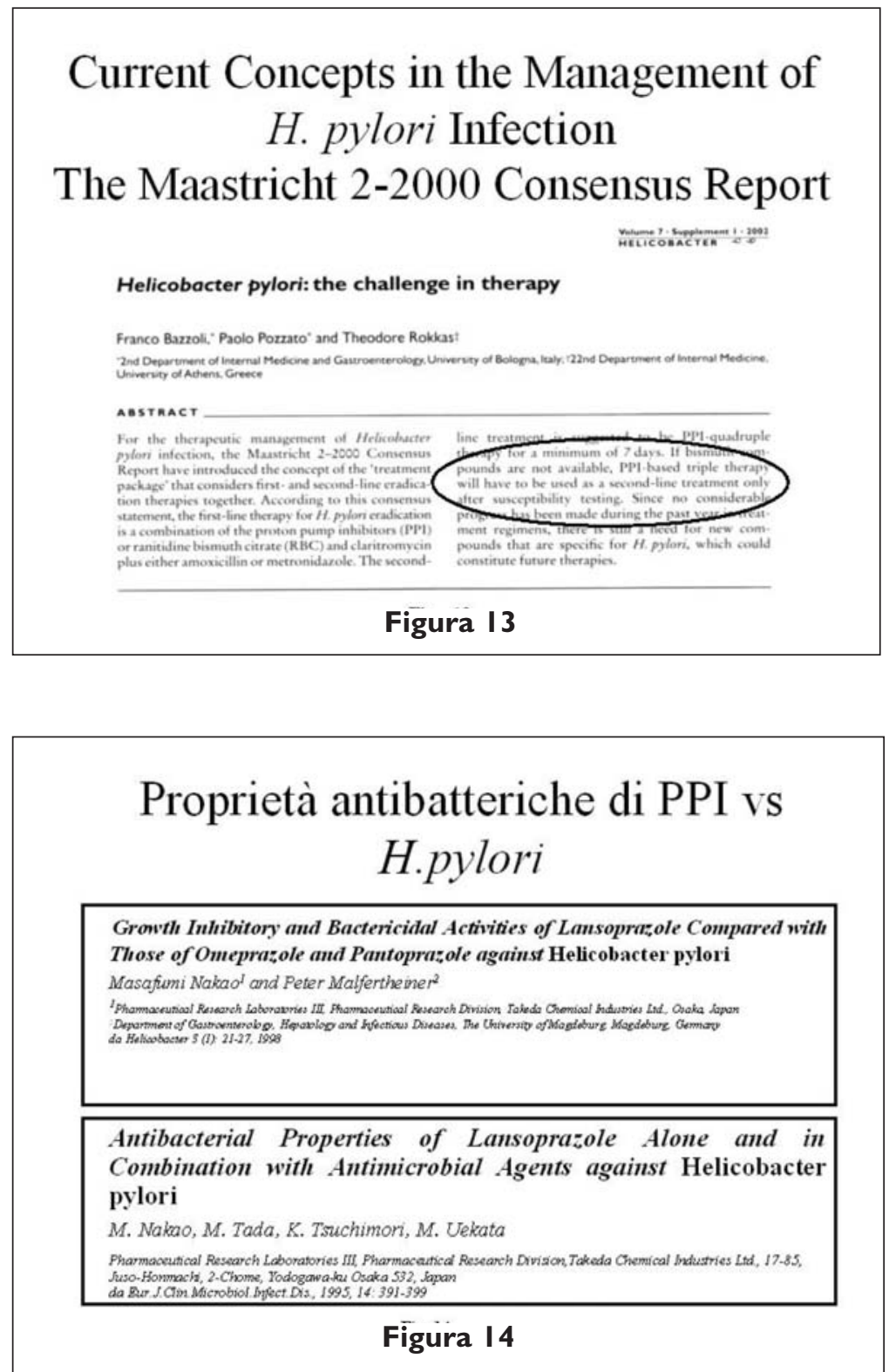

\section{BIBLIOGRAFIA}

1. Adamek R., Suerbaum S., Pfaffenbach B. et al. Primary and acquired H. pylori resistance to clarithromycin, metronidazole and amoxycillin - influence on treatment outcome. Am J Gastroenterol. 1998; 93: 380-9.

2. Boyanova L., Spassova Z., Krastev Z. et al. Characteristics of trends in macrolide resistance among $\mathrm{H}$. pylori strains isolated in Bulgaria over four years. Diag Microbiol Infect Dis. 1999; 34: 309-13.

3. Broutet N., Guillon F., Sauty E. et al. Survey of the in vitro susceptibility of Helicobacter pylori to antibiotics in France. Preliminary results. Gut 1998; 43 (suppl. 2) :A11

4. Buckley MJM, Xia HX, Hyde DM et al. Metronidazole resistance reduces efficacy of triple therapy and leads to secondary clarithromycin resistance. Dig Dis Sci. 1997; 42: 2111-5

5. Cayla R., Lamouliatte H., Brugmann D. et al. Pretreatment resistances of $\mathrm{H}$. pylori to metronidazole and macrolides. Acta Gastroenterol Belg. 1993; 56: 65
6. Chaves S.,Gadanho M., Tenreiro R., Cabrita J. Assessment of Metronidazole Susceptibility in Helicobacter pylori : Statistical validation and Error Rate Analysis of Breakpoints Determined by the Disk Diffusion Test .J Clin Microbiol. 1999; 37 : 1628-163

7. De Boer WA., Tytgat GNJ. How to treat H. pylori infection. Should treatment strategies be based on testing bacterial susceptibility? A personal viewpoint. Eur J Gastroenterol Hepatol. 1996; 8: 709-16.

8. De Paula las Rua L., Aleixo A., Brazilian consensus on Helicobacter pylori and associated diseases. Acta Gastroenterol Latinoam. 1996; 26: 255-60.

9. Dore M. P., M. Osato, David Y. Graham et al. Amoxicillin tolerance in Helicobacter pylori. J. Antimicrob. Chemoter. 1999; $43: 47-54$

10. Dore M. P. et al. Effect of pretreatment antibiotic resistance to metronidazole and clarithromycin on outcome of Helicobacter pylori therapy: a meta-analytical approach.

Dig Dis Sci. 2000; 45: 68-76

11. Ducons J., Santolaria S., Guiro R. et al. Impact of clarithromycin resistance on the effectiveness of a regi- 
men for H. pylori: a prospective study.

Aliment Pharmacol Ther. 1999; 13: 775-80.

12. European Helicobacter pylori study group. Current European concepts in the management of Helicobacter pylori infection.Maastricht consensus report.

Gut 1997; 41: 8-13.

13. Fauchère JL. Validation of a disk diffusion method for macrolide susceptibility testing of Helicobacter pylori. Gut 1999; 45 (suppl. 3): A9

14. Fedorak R., Archombault A.; Flamm R. et al. Antimicrobial susceptibility of $\mathrm{H}$. pylori in Canada. Gastroenterology 1997; 112: A115

15. Gibson JR., Saunders NA., Burke B., Owen RJ. Novel method for rapid determination of clarithromycin sensitivity in Helicobacter pylori. J Clin Microbiol. 1999; 37: $3746-8$

16. Glupczynski Y. Culture of Helicobacter pylori from gastric biopsies and antimicrobial susceptibility testing.

In: Lee A., Mégraud F. Helicobacter pylori: technique for clinical diagnosis and basic research. London : Saunders Company Ltd, 1966 : 17-28.

17. Glupczynski Y., Binette A, Lang P. et al. Evolution of primary resistance to antimicrobial agents in Belgium between 1995 and 1998. Gut 1998; 43: A48

18. Glupczynski Y., Mégraud F., Andersen LP., LopezBrea M. Antibiotic susceptibility of Helicobacter pylori in Europe in 1998: results of third multicentre study.

Gut 1999; 45 (suppl. 3): A3

19. Graham DY, Antibiotic resistance in Helicobacter pylori: implications for therapy. Gastroenterology,1998; 115: 1272-7

20. Graham DY, de Boer WA, Tytgat GNJ. Chosing the best anti-Helicobacter therapy: effect of antimicrobial resistance. Am J Gastroenterol. 1996; 91: 1072-6

21. Houben MHMG, van de Beek D., Hensen EF et al. A systematic review of Helicobacter pylori eradication therapy: the impact of antimicrobial resistance on eradication rates.

Aliment Pharmacol Ther. 1999; 13: 1047-55.

22. Kist M, Strobel S, Folsch US, Prospective assessment of the impact of primary antimicrobial resistance on cure rates of Helicobacter pylori infections.

Gut 1997; 41(suppl. 1): A90

23. Iovene MR., Romano M., Pelloni AP. et al., prevalence of antimicrobial resistance in 80 clinical isolates of H. pylori. Chemotherapy 1999; 45: 8-14

24. Jenks PJ, Ferrero RL., Labigne A. The role of the rdxA gene in the evolution of metronidazole resistance in helicobacter pylori. J Antimicrob chemother. 1999; 43: 753-8

25. Lahaie R.G., Gaudeau C., Tremblay C. et al. In vitro evaluation of $\mathrm{H}$. Pylori pre-treatment antiiotic resistance and evaluation of the disk diffusion test. CHUM - Pavillon St. Luc, Montreal, PQ 1999

26. Leibovici L., Shraga I., Andreassen S. How do you choose antibiotic treatment? BMJ 1999; 318: 1614-8.

27. Malfertheiner P., Nilius M. Diagnosi dell'infezione da Helicobacter Pylori.

In: Malfertheiner P. Helicobacter pilori. Dai concetti basilari alla terapia.

Roma: Micarelli Editore, 1995 : 73-74.

28. Marais A., Monteiro L., Occhialini A., Pina M., Lamouliatte H., Mégraud F. Direct detection of Helicobacter pilori resitance to macrolides by a polymerase chain reaction/DNA enzyme immunoassay in gastric biopsy specimens. Gut 1999; 44: 463-7

29. Matsuoka M., Yoshida Y., Hayakawa R. et al. Simultaneous colonisation of $\mathrm{H}$. pylori with and without mutations in the $23 \mathrm{~S}$ rRNA gene in patients with no history of clarithromycin exposure. Gut 1999; 45: 503-7.

30. McNulty Cliodna, R. Owen, D. Tompkins, P. Hawtin et al. Helicobacter pylori susceptibility testing by disc diffusion. J Antimicrob Chemother. 2002; 49: 601-609

31. Mégraud F., H P Doermann Clinical relevance of resistant strains of Helicobacter pylori: a review of current data. Gut 1998; 43 (suppl. 1) : S61-S65)

32. Mégraud F., Epidemiology and mechanism of antibiotic resistance in Helicobacter pylori.Gastroenterology, 1998; 115: 1278-82

33. Miyaji H., Azuma T., Ito S., Susceptibility of Helicobacter pilori isolates to Metronidazole, Clarithromycin and Amoxicillin in vitro and in clinical treatment in Japan. Aliment Pharmacol Ther. 1997; 11: 1131-6.

34. Nakao M., Malfertheiner P. Growth Inhibitory and Bactericidal Activities of

Lansoprazole Compared with Those of Omeprazole and Pantoprazole against Helicobacter pylori. Helicobacter 1998; 3 (1): 21-27

35. Nakao M., Tada M., Tsuchimori K., Uekata M. Antibacterial Properties of Lansoprazole Alone and in Combination with Antimicrobial Agents against Helicobacter Pylori

Eur.J.Clin.Microbiol.Infect.Dis. 1995; 14: 391-399

36. NCCLS Acceptable Quality control Limits of Minimum Inhibitory Concentrations (MICs) $(\mathrm{mg} / \mathrm{mL}$ ) for Fastidious Organisms Document M7 - A4 ; Table 3A : 98 - 99.

37. NCCLS Performance Standard for Antimicrobial Susceptibility Testing January 2002 Document M100 - S12 ; table 2J : 108

38. NHI Consensus Conference. Helicobacter pilori in peptic ulcer disease.

J Am Med Assoc. 1994; 272: 65-9

39. Occhialini A., Urdaci M., Doucet-populaire F., Bébéar CM., Lamouliatte H., Mégraud F.

Macrolide resistance in helicobacter pylori : rapid detection of point mutations and assays of macrolide binding to ribosomes. Antimicrob agents Chemother. 1997; 41: 2724-8

40. Osato M., R. Reddy, D.Y.Graham et al. Reliable Determination of Metronidazole and Clarithromycin Susceptibility: Comparison of Methods and Assessment of Internal Variability using simultaneously obtained Antral and Corpus Biopsies.

Gastroenterology April 2000; 118 (nr.4) : 3699

41. Perri F, Festa V, Andriulli A. Treatment of antibiotic resistant Helicobacter pylori infection. N Engl J Med 1999; 339: 53

42. Pieramico O., Zanetti MV., Innerhofer M. and Malfertheiner P.

Omeprazole-Based Dual and Triple Therapy for the Treatment of Helicobacter pylori Infection in Peptic Ulcer Disease: A Randomized Trial. Helicobacter 1997, 2: 92 - 97.

43. Pieramico O, Zanetti MV. Treatment with quadruple therapy after triple therapy failure in patients infected with H.pilori resistant strains. Gastroenterology,1999; 116: A282.

44. Pieramico O, Zanetti MV. Treatment of clarithromycin resistance of $\mathrm{H}$. pylori: A Comparison between triple and quadruple therapies. Gut 2002 ; 51 (suppl. II): A 97.

45. Rüssmann H. et al. Comparison of Fluorescent In Situ 
Hybridization and Conventional Culturing for Detection of H. Pylori in Gastric Biopsy Specimens. J Clin Microbiol. 2001; $39: 304-308$

46. Rüssmann H. et al. Rapid and Accurate Determination of Genotypic Clarithromycin Resistance in Cultured H. pylori By Fluorescent In Situ Hybridization.

J Clin Microbiol. 2001; 39 : 4142 - 4144

47. South African Medical Association. South African Gastroenterology Society Group.

Diagnosis and management of dyspepsia - clinical guideline, 1999.

S Afr Med J. 1999; 89: 897-907.

48. Tankovic J., Lamarque D., Lascois C., Delchier J. Primary and Secondary Clarithromycin (CLA) Resistance of H.pylori.

Gut 2000; 47 (suppl. 1): A105

49. Vakil N., Hahn B., McSorley D., Clarithromycin-resistant H. pylori in patients with duodenal ulcer in the United States. Am J Gastroenter. 1998; 93: 1432-5.

50. Vandenplas Y. Helicobacter pylori infection. Clin Microbiol Infect. 1999; 5: 1-11.

51. Van Doorn LJ., Debets-OssenkoppYJ., Marais A. et al. Rapid detection, by PCR and reverse hybridization, of mutations in the Helicobacter pylori $23 \mathrm{~S}$ rRNA gene, associated with macrolide resistance. Antimicrob Agents Chemother. 1999; 37: 3746-8

52. Van der Hulst RWM, van 't Hoff BWM. Treatment of Helicobcter pylori eradication failure. Gastroenterol Int. 1997; 10: 153-60.

53. Van der Wouden EJ, Thys JC, van Zweet AA et al. The influence of in vitro nitroimidazole resistance on the efficacy of nitroimidazole containing antiHelicobacter pylori regimens: a meta-analysis. Am J Gastroenterol. 1999; 94: 1751-9.

54. Van Zweet A.A., Vanderbrouke-Grauls C M J E, Thys $\mathrm{J} \mathrm{C}$ et al. Stable Amoxycillin Resistance in Helicobacter pylori. Lancet 1998; v. 352 :1595.

55. Van Zweet A.A., Bner WA, Schneeberger P et al. Prevalence of primary Helicobacter pylori resistance to metronidazole and clarithromycin in the Netherlands.

Eur J Clin Microbiol Infect. $1996 ; 115$ : 861-4

56. Von Doorn L., Debets-Ossenkopp Y., Morais et al. Rapid detection by PCR and reverse hybridisation of mutations in the Helicobacter pylori 23S rRNA gene, associated with macrolide resistance. Antimicrob Agents Chemother. 1999; 43: 1779-82.

57. Wolle K., Nilius M., Leodolter A., Malfertheiner P. Prevalence of Helicobacter pylori resistance to several antimicrobial agents in a region of Germany. Eur J. Clin Microbiol Infect Dis. 1998 Jul; 17(7): 519 - 21.

58. Xia HX, Keane CT, Beattie S, O' Morain CA . Standardization of disk diffusion test and its clinical significance for susceptibility testing of metronidazole against Helicobacter pylori. Antimicrob. Agents Chemoter. 1994; $38: 2357-61$

59. Xia HX, Keane CT, Buckley MJM, O’ Morain CA. Clarithromycin resistance in Helicobacter pylori: prevalence in untreated dyspeptic patients and stability in vitro.

J Antimicrob Chemother. 1996 ;37(3) :473-481.

60. Zanetti MV., Pieramico O., Vendramin R. In vitro Resistance of Helicobacter pylori to Metronidazole and Clarithromycin: a quadrennial retrospective investigation

Clin. Microbiol Infect 2001; 7 (suppl. 1): 335

61. Zanetti MV., Vendramin R., Pieramico O. Fluorescent in situ hybridization for assessment of clarithromycin resistance of Helicobacter pylori in gastric bioptic specimens: A comparison with disk-diffusion technique.

Gut $2002 ; 51$ (suppl. II) : A5. 